\title{
FROM ISOLATION TO READAPTATION. CONVICT AS THE SUBJECT OF PENITENTIARY POLICY
}

\begin{abstract}
The author, based on the available literature and his own professional experience in the police service, analysed the state of the penitentiary policy applied to convicts. He took into account and characterized the background of the activities performed as part of the execution of the imprisonment sentence in the People's Republic of Poland until 1989 and the solutions applied after the systemic transformation, indicating the status of the convict within the framework of rehabilitation procedures. He presented solutions in the area of social rehabilitation of prisoners and the possibility of their return to social life. In addition, he referred to the sociological basis of social rehabilitation as part of supervised freedom.
\end{abstract}

KEYWORDS: convict, penal institute, penitentiary system, rehabilitation, social readaptation

\section{INTRODUCTION}

Searching for legal solutions to combat crimes involves many legal and social difficulties, regardless of the period when crime is committed. Undoubtedly, they include the evolution of crime, its dynamics and the degree to which the crime is organized using the tools available in a given 
period (Such-Pyrgiel, 2019, s. 170). Nota bene, the subject of a criminal attack remains at the centre of attention for the security guardians, judicial authorities and institutions responsible for the execution of a sentence.

It seems reasonable to pose a question whether the direction of the state's policy with regard to combating crime is adequate to the expected effects of social impact, i.e. whether there is rehabilitation that prompts the perpetrator of a crime subjected to the penal institute conditions to fight for his place in the society. Attempt against the good protected by law is withdrawal from society, a breach of the fundamental principles of functioning of the human community due to violation of its norms and principles. The fundamental issue, which is frequently neglected by those responsible for the implementation of criminal policy, both on scientific and legal grounds, seems to be the fact that they disregard the necessity to possess capital by the convict, which he can contribute as part of secondary internalisation in the social environment. In the isolation, regardless of its form, he should accumulate values and acquire socially useful attitudes and skills.

The perpetrator of the crime rarely recognizes that he is responsible for coming into conflict with the law, and usually points to the malfunction of the social structures and blames the state that created the conditions for him to commit the crime. The point observed in the analysis of the situation seems to be reasonable in connection with the interpretation of the damage that he caused, regardless of whether the injured party is a complete stranger or someone close.

The evolution in the manner of the execution of a sentence ranging from death execution to the Electronic Surveillance System revealed the weaknesses of the methods and tools used towards perpetrators at the turn of the century and their ineffectiveness in the face of social threats. Uncontrolled thoughts lead the convict to believe that after leaving the penal institute, it is the society that must ensure that he can start a new life outside the walls, and that society is obliged to provide him the conditions to do so.

This may result from the development of social impairment in the perpetrator while serving a sentence of imprisonment, especially in prisoners serving long sentences who do not have the predisposition to ensure their basic 'existential needs' in accordance with the law. 


\section{EXECUTION OF THE SENTENCE - MEASURES AGAINST THE PRISONER}

The legal act regulating the execution of a sentence is the Executive Penal Code, which stipulates the course of enforcement proceedings. It has been amended many times as a result of socio-political changes in connection with the legislative process in the area of penal sanctions for committing a prohibited act during the validity of the act. The convergence that we encounter results from the political impact on the law-making. The post-war period, saturated with the ruthless use of the argument of force and collective isolation, resulted from the demand of the power apparatus to overcome the dissimilarity in perceiving the post-war reality of Poland and the vision of a free state. It was reflected in the repression of convicts in line with the only right ideology, with the use of high punitiveness, which affected the number of convicts in prisons and their status. As part of the penalty measures, the absolute imprisonment was commonly used. On the legal and criminal grounds, the purpose of the punishment moved into the background, and the standards were stipulated at successive conventions of the Polish United Workers' Party. In the literature, the situation of convicts is clearly and unambiguously perceived the prism of political interest: “ ... imprisonment was a tool for consolidating communism in Poland, while the penitentiary system in the Polish People's Republic specialized in the cheapest possible detention of as many people as possible" (Stepniak, 2009, p. 79).

The end of the period of consolidating the people's power in the People's Republic of Poland, conventionally referred to in the literature as 1956 is, according to $\mathrm{H}$. Machel, the time of departing from the strictly political function of the Polish prison system. Such interpretation seems to result from the course of events that led to the adoption of new penal codes in 1969, where: “... political considerations were less emphasized” (Stepniak, 2009, p. 79). The newly created law put the prisoner in a new framework, pointing to the change of priorities in penitentiary solutions, which was reflected in the clear focus on the improvement of the convict and the social rehabilitation attitudes. However, bearing in mind the real situation of the People's Republic of Poland, the new regulations received politically correct interpretation in the form of a commentary introducing to the provisional regulations of 1974 
on the execution of imprisonment sentence: “... upon the resolution of the congress it is required that the public order and justice authorities decisively and consistently combat abuses and crimes against social property and all acts detrimental to the vital interests of the state and citizens" (Stepniak, 2009 , p. 80). Therefore, the issue of the convicts' rehabilitation was de facto 'swept away' by the overriding interest of political party, which interpreted the scope and the manner of educational impact on convicts in a way suitable for them. Not without significance is also the fact that the representatives of the prison system interpreted the basic objectives of the execution of a sentence in their own way. An adequate example of the so-oriented thinking based on the guidelines of the PZPR 6th Congress is the standpoint of the Director of the Central Board of Prisons as of February 1972:

"... the main irregularity in penitentiary work organization was the fact that the rights and powers of the prisoners were often exposed, while the enforcement of duties moved to the background ... . The prison service did not sufficiently, often even maybe submissively, enforce the requirements and obligations of the convict in order to develop a socially desirable attitude, teach them to perform socially useful work and respect the order and discipline. (...) in the regulations on the execution of imprisonment sentence of 1966, the convicts' rights were emphasized, while the ailments factor was blunted, and a variety of disciplines was developed, which - considering the practical conditions of prisons - was unfeasible." (Stepniak, 2009).

As soon as solutions related to the redefinition of the attitudes and goals of executing sentences appeared, attempts were made to standardize the penitentiary policy, considering the previously existing criminal record of convicts and focusing on the social harmfulness of the act and the degree of its demoralization. In the early 1970s, the prison management looked at the issue of imprisonment execution through the prism of the effectiveness of its enforcement, which was understood as effective prevention of crime and was treated as a general prevention tool, an inhibitory factor and a sort of deterrent. The social message of the application of such procedures was supposed to be clear and unambiguous for potential perpetrators of crimes who, intending to commit a crime harmful to the social welfare and the state, would be sent to a penal institute. On the basis of the adopted assumptions, appropriate 
directives were formulated referring to the functioning of penitentiary model of impact. They took on an evaluative dimension and were primarily focused on enforcing the fulfilment of duties on the convict, pointing to the overriding social interest to which the individual interests of the convict should be subordinated. The issues of the convict's rights under the laws and legal acts constituting executive regulations moved to the background and did not constitute an integral part of the penitentiary model of impact. Another very important element of the activities turned out to be the restrictions imposed on the manner of executing penalty measures against previously convicted and dangerous criminals. The application of relief and mitigation measures was also clearly limited to perpetrators of crimes committed inadvertently, with a low degree of social harmfulness, as well as to women and adolescents who were convicted for committing a prohibited act. The fourth directive, significant for the execution of a sentence in that period, was the focus on the intensification of efforts aimed at dividing prisoners, using a mixed system based on progression and regression.

The following decades did not bring a change in the approach to the function of executing a sentence with consideration of its basic purposes; relying mainly on political directives adopted a repressive-isolation model. It seems reasonable to note that attempts were made to influence the prisoners by introducing the first educators, cultural and educational activities, etc. to prisons, operating within the autonomy granted to the heads of prisons. Subsequent amendments to the Executive Penal Code did not bring about a fundamental change in affecting the prisoners; the conditions and manner of the execution of the imprisonment sentence were maintained at a similar level, all changes in this matter were clearly cosmetic and did not put the rehabilitation of the convict in the centre of attention, but the regulations. An example illustrating this reality may be the reference to the work performed by the convict. The resistance to perform work by the convict, nota bene not treated as a right but a duty by the convict, ended with the application of a disciplinary procedure, i.e. shaping a negative attitude towards work as another penalty. The effect of the penitentiary policy pursued with view to excluding convicts from society by their maximum isolation was the creation of a prison community, which is a substitute for a social organization 
operating outside the walls of prisons. The created social model is guided by its own principles and is determined by the prisoners' needs, regarding the hierarchy and needs of that environment. How does the stay in the penal institute affect the convict? Henryk Machel attempted to answer this question: “... Penitentiary isolation causes depletion of needs, frustration, and forces to behave in a certain way, normal family life is interrupted or very limited, and the personality hardens" (Machel 2009, p. 103).

Due to the fact that these considerations are not intended to present the history of the Polish prison system step by step, but are only an analysis of the state and activities carried out in particular periods, it is justified to conclude that the penitentiary policy of 1945 to the political changes of 1989 did not bear the hallmarks of rehabilitation.

\section{NEW SYSTEMIC REALITY OF 1989 - NEW STANDARDS}

The political transformation in Poland has changed the perception of all areas of Polish life. The transition from a command-and-control economy to a free-market model impelled changes in the law, which had a direct impact on shaping the penitentiary policy. Despite the concerns of many circles with regard to the imperfection of the law being created, the liberal treatment of the perpetrator of crimes by using the threat of penalty, provisions of the Penal Code, the Code of Criminal Procedure and the Executive Penal Code entered into force in 1997.

The new approach to the perpetrator of a crime, indication of the circumstances that may affect the mitigation of a sentence, the manner of its implementation and the possibility of using other types of impact measures targeted directly at the convict created a new dimension of work organization with the convict. It is reasonable to start analysis in this matter with the classification of prisons operating in the Polish penitentiary system. The basic division of penal institutes results from the degree of supervision over convicts: “ ... closed prisons, semiopen prisons and open prisons” (Limanowski, 2017, p. 82).

The very classification of the convict to which penitentiary facility will be send indicates that the model of proceedings is individualized in relation to a specific perpetrator of the act, subjected to the influence within 
the penitentiary policy, far from the previously used solutions limiting the aggravation of demoralization and undesirable behaviour. The main difference between the various types of penitentiary facilities consists in the degree of security, level of isolation of the convicts, their rights and obligations (nowadays the rights come first), i.e. the size and nature of freedom, the possibilities of moving inside and outside the prison, the level of maintaining contact with external environment.

Currently, there are three systems of serving a sentence of imprisonment: 1 ) system of programmed influence, 2) therapeutic system, 3) ordinary system. Since the question is about the system with regard to the penitentiary effects, it may be practical to refer to the basics, i.e. what a system is. The definition of a system as a specific method of proceeding and performing some activity is described by Krzysztof Limanowski as: “ ... a coordinated system of elements, a set that forms a whole, conditioned by a constant, logical ordering of its components." (Limanowski, 2017, p. 93).

The scheme and standard treatment of prisoners known from the past has fallen into oblivion. Imposing changes in behaviour and trying to force certain reactions that do not cause permanent changes in the behaviour of the offender have been questioned and considered an ineffective form of influence. Nowadays, the attitudes of adolescents who are under the age of 21 and obliged to participate in this form of serving a sentence are shaped within the framework of the programmed impact system. It does not mean, however, that adults cannot benefit from this form of imprisonment, too; the essential condition is consent to participate in the creation and implementation of the proposed project of impact. It is the perpetrator of a crime who partly becomes the initiator and, at the same time, the executor of the program within which he gains the ability to overcome challenges in freedom. The effectiveness of this method - considering the fact that the convict has been motivated, commits himself voluntarily, and perceives it as a benefit for himself, it may constitute a social rehabilitation space where there is room for education, cultural and sports activities, social activity and contact with the outside world. There is no an unambiguous assessment whether this form of punishment can be addressed to everyone, yet constitutes a hint which direction to take in combating crimes and creating grounds for re-adaptation 
or going further into social reintegration. In order to meet the expectations of a convict serving a sentence in the system of programmed impact, he is placed in a semi-open prison, which significantly contribute to shaping his responsibility for the effects of social rehabilitation activities.

Also offenders with mental disorders and physical defects are sent to prisons; for them the therapeutic system is valid. This form of punishment is served by convicts: who exhibit non-psychotic mental disorders, with severe mental deficits, addicted to alcohol, drugs and similar pharmacological agents (psychotropic drugs). Performing punishment within the framework of the therapeutic system aims to prevent the development of pathological personality traits, achieve a state of mental balance by the convict, develop skills necessary to be able to function in society as well as the ability to exist independently.

The essence of this form of punishment is the convict's conscious participation in the procedure including this form of punishment expressed through acceptance of the therapeutic program and the ward regulations. The type and forms of therapeutic activities are tailored to a specific convict, with consideration of his needs in this area as well as the possibility of using the immediate environment (family) in the therapy and planned activities.

The use of therapy in the execution of punishment clearly points to the principle of individualization, i.e. a professional approach to a specific convict without using a collective template. Based on the knowledge about the genesis of crimes and the factors determining their commission by a specific convict, it is possible to use appropriate therapeutic tools and methods to extinguish criminal behaviour using the family as part of therapy. Using the component of immediate environment stimulates the process of shaping the desired attitudes and changes in the perception of reality with regard to social functioning and proper evaluation of values. It is a sort of preparation of the relatives for the return of the convict to the natural environment after the correction stage. The therapeutic system focuses on the empowerment of the convict, which, according to the assumptions adopted, creates a platform for effective social rehabilitation based on the convict's commitment expressed in his voluntary participation in therapeutic interventions.

The ordinary system of serving a sentence of imprisonment is for convicts who do not require programmed or therapeutic interventions, as well as for 
prisoners (including adults) who have violated the rules of imprisonment in this mode or have not accepted participation in the development and implementation of an individual program of impact. A convict in this system has the right to work, participate in sports, cultural and educational activities offered by the penitentiary institute. The main objective is to achieve individual-preventive goals. However, it should be noted that the current legal references allow the convict to choose the system of execution of imprisonment sentence by himself and orders to respect his decisions: „... leaving the decision to the convict as to whether to serve a sentence in the system of programmed impact or ordinary system does not mean that the convicts who do not choose the system of programmed impact, abandon the positive impacts" (Limanowski, 2017, p.107).

Considering the problem from the sociological level, it seems justified to look at the punishment from pragmatic perspective, which is possible if the actions are adopted and approved by the convict. Work is an alternative, and it is the convict's way to manage time and get familiar with a different dimension of existence, completely unknown to him due to the pathological style of life determined by the amount of alcohol consumed, psychoactive substances administrated that distort the space and time. This process of life materialization indicates the benefits of performing work, including the acquisition of skills, manual skills allowing to obtain qualifications and thus the possibility of finding himself on the labour market after leaving the penal institute. While performing work, a convict receives remuneration that can be allocated to his own needs as well as to meet the needs of the family. The awareness of gaining social independence, perceived as the ability to satisfy basic living needs, is a motivation for the development of mental abilities that condition the "normal" functioning in the social structure. An essential element of the convict's return to the external environment and gaining acceptance in the area of social activity is de-stigmatization as a result of which the offender, after serving a sentence of imprisonment, takes actions that are accepted by the public. Entering the next stage of social rehabilitation with the society involved aims to verify the acquired and shaped abilities and attitudes by participation in social relations. To use an adequate example that allows the convict to show the society a "new face", one can refer to the 
situation where the convict on his own initiative undertakes activity for the benefit of others. "... For example, in the United States, if a serial killer in a disciplinary camp, in the event of a natural disaster, voluntarily, risking his life, saves others' lives, the society asks the governor or the president to cancel his punishment" (Baładynowicz, 2011, p. 201).

Speaking about the US penitentiary practice, it is worth paying attention to the "boot camp" to which young people, adults, including men and women are sent; their creation was caused by overpopulation in prisons and was experimental. This type of imprisonment was referred to as "moderate punishment instead of imprisonment” (Baładynowicz, 2010, p. 52).

The creators of this form of imprisonment adopted assumptions that aimed to meet social expectations in the field of protection of society against criminals by imposing strict control during the stay in the disciplinary camp and after its leaving. The creation of a new formula of the execution of a sentence aimed to solve the problem of overcrowding and allowed for the relaxation of the rigors in the execution of a sentence under conditions of supervised freedom. In the project, the economic dimension was also taken into account by introducing shorter period of executing a sentence and thus reduction of its execution costs. Considering the local reality, prisoners were deprived of some privileges they could enjoy when serving a sentence in the traditional formula.

In disciplinary camps, work is compulsory as a form of compensation for the victim of the crime and for society that has suffered the consequences of the crime. The goals set for convicts include self-discipline, habit of work, creation of pro-social attitudes as well as maintaining health and good physical condition. In order to ensure optimal effects, some camps use therapeutic, healing and educational methods.

The digression on the forms of imprisonment used in the USA aims to present the state of the Polish solutions in this matter.

However, before the convict leaves the penal institute, it is advisable to look at his freedom from the perspective of the environment to which he returns. The complexity of personal and environmental contacts constitutes a burden for him, which forces him to stay in the "former life" through the secondary internalization of norms, rules and lifestyle accepted in the native environment. The post-penitentiary reality was quite accurately presented 
by B. Skafariak, quoted by Krzysztof Limanowski with regard to social readaptation, which depends: “... mainly on the convicts, due to inter alia the criminogenic conditions of the environment to which they may return after serving their sentence. The success of this complex process also depends on social culture. In order to enable continuation of the process of social reintegration outside the penal institute, an interest in other human being and the problems related to the transition from isolation to social freedom is needed. Acceptance, tolerance, positive social attitude towards people in the phase of social re-socialization require a change in the mentality of society, profit-oriented assistance to people leaving prison, which would pay off in the quality of our life, preventing the convicts to believe that upon their release they start a real imprisonment in freedom”. (Bębas, 2010, p. 135).

Referring to some of the statements, it is impossible not to refer to very important issues that cannot be left without a comment. Committing a crime, e.g. against life and health in the psychological perpetrator's perception, did not generate trauma for him; in many cases it is a state associated with a positive, pleasant psychological experience - an ego enhancement. Does the perpetrator feel the burden of his act? As much as he is aware of the crime consequences suffered by the victim. The social image of justice that consists in determination, arresting, and judgment of the perpetrator, and in the longer term, placement in a penal institute never compensate for the harm in a form of health loss or death. How is the victim and their relatives perceived in the local community? What image of the social reaction the victim confronts while experiencing secondary victimization? The developed social sensitivity does not always provide conditions for the injured party (victim) to successfully undergo re-adaptation with the burden of harm, pain and slsyndrome of helplessness and loneliness written on his forehead, often sealed with social stigmatization. The penalty of imprisonment shown as social compensation; the form of compensation for the harm done seems to be a half-measure, it is a form of punishment for the perpetrator, it is another consequence for the society that pays for his guilt once again - in the literal sense.

Therefore, how is the society supposed to react when a killer is released? It is hard to expect them to accept it with enthusiasm, being aware of the dangers posed by the presence of such a person in the immediate vicinity. 
Apart from the state of self-defence, it is difficult to find arguments that could justify the use of violence against another person. Social awareness, shaped by the media, does not make the "act of forgiveness" easy for the perpetrator. It is not the society that should adapt to the perpetrator in the post-penitentiary reality, but he who should strive for relative treatment not to be rejected.

The stay in a penitentiary facility is described in the literature as a circumstance that generates psychological consequences, including the process of depersonalization, i.e. „ ... a subjective experience of an internal emotional change as a sense of strangeness or feeling unreal (Ciosek,1996, p.162). Completing the imprisonment sentence is a situation in which the convict has a chance to make himself real by offering the society something that deprived him of the guarantee of security and confidence.

\section{ConCLUSION}

The history of mankind has always been associated with the manifestations of behaviours with a pejorative impact on the social structure, taking different images and forms. The system of applying penalty and its gradation has never been and it seems unlikely that it will ever be perfect. The gallows execution, decapitating Roman citizens with a sword, imprisonment behind bars, often combined with starvation and even the use of torture, has never brought $100 \%$ certainty that the perpetrator would not return to the path of crime. For obvious reasons, it should be assumed that all legal and criminal solutions (Executive Penal Code) are a post factum action. Scaring a potential offender with the inevitability of punishment has ceased to evoke the expected reaction; maybe the time has come not to focus all attention on the inevitability of punishment, on defining the boundary of the sentence, but to take a closer look at the prevention issues as a pre-emptive activity. The prevention costs will always be lower than the costs of actions taken after committing a crime and eliminating its consequences. Indication of the consequences of violating the fundamental rights of another human being, attempt against the good protected by law (which is his life and health) is the major direction to follow. Before the perpetrator raises his hand against the subject of his attack, he should be aware of the effects of his actions, which is believed to 
be the responsibility of "social legitimacy", i.e. the loss of belonging and the rights assigned to everyone. The time spent in prison is the time to realise the guilt and accumulate the capital necessary to convince the society of the prisoner's value, i.e. his usefulness for the social organization. When realised from the prison, the perpetrator does not put on a "white robe"; he is still a criminal who has to earn social trust and struggle with adversities caused by himself. Society is only a space where he has to build its own home again, taking care of good contacts with its neighbours. Although the presented standpoints and opinions of the author may disturb the generally accepted tone, it is worth paying attention to the good protected by law recognized as the tangible and intangible value of the victim as a result of the crime. The convict's path from isolation to his personalized presence in the social sphere behind the prison wall is a punishment, although he is not aware of it and must go through it on his own with courage and responsibility, otherwise he will return to the starting point.

\section{References}

Baładynowicz A.(2011), Probacja - resocjalizacja z udziałem społeczeństwa, wydawnictwo Warszawa: Wolters Kulwers business, s.201. ISBN 9788326414916.

Baładynowicz A.,(2010) Probacja kwartalnik II/2010, Warszawa: wydaw. Ministerstwo Sprawiedliwości, s.52. ISSN 1689-6122.

Bębas S. (red.) (2010), Współczesne oblicze resocjalizacji penitencjarnej, Radom: wyd. Wyższa Szkoła Handlowa w Radomiu, s. 135. ISBN 9788362491056.

Ciosek M.,(1996) Człowiek w obliczu izolacji więziennej, Gdańsk: wyd. Archidiecezji Gdańskiej „Stella Maris”, s.162. ISSN 8385111174.

Limanowski K.,(2017) Organizacja i zadania służby więziennej w Polsce, Radom: wyd. Wyższa Szkoła Handlowa w Radomiu, s.82. ISBN 9788362491483.

Machel H,(2009) Wybrane problemy i zadania więziennictwa polskiego, „Przegląd Więziennictwa Polskiego" nr 62-63 s.103, Warszawa: Wydawnictwo Centralnego Zarządu Zakładów Karnych Ministerstwa Sprawiedliwości, s.103. ISSN 1230-4433.

Stepniak P.,(2009) Przemiany w polskim więziennictwie, a model oddziaływań wychowawczych „Przegląd Więziennictwa Polskiego” nr 62-63, Warszawa: Wydawnictwo Centralnego Zarządu Zakładów Karnych Ministerstwa Sprawiedliwości, s.79. ISSN 1230-4433. 
Such-Pyrgiel, M. (2019) Człowiek $w$ dobie cyfrowej transformacji. Studium socjologiczne, Toruń: Wyd. Adam Marszałek. ISBN 9788366220966.

Witkowska-Paleń, A. (2015). Programy wspierajace proces readaptacji społecznej skazanych $w$ zakładach karnych (Wybrane przykłady). Journal of Modern Science, 25(2), 177-194. 